\title{
Differential MHC-ח, IL-8 and IgM genes expression in the liver, head Kidney and gill tissues of juvenile rainbow trout (Oncorhynchus mykiss) immunized by inactive trophonts of Ichthyophthirius multifiliis
}

\author{
M. Heidarieh ${ }^{1}$, M. Akbari² , H. Unger3 \\ ${ }^{1}$ Nuclear Science and Technology Research Institute, Karaj, Iran \\ ${ }^{2}$ Department of Fisheries Science, Gorgan University of Agricultural Sciences and Natural Resources, Gorgan, Iran \\ ${ }^{3}$ Animal Production and Health Laboratory, International Atomic Energy Agency (IAEA), Vienna, Austria
}

\section{- Original article}

\section{*Corresponding author: \\ Marzieh Heidarieh, Ph.D., \\ E-mail:}

haidariehm81@gmail.com

Revised: November 2020

Accepted: December 2020

Int. J. Radiat. Res., October 2021; 19(4): 955-962

DOI: $10.29242 /$ ijrr.19.4.955

\begin{abstract}
Background: The current study was designed to compare the genes expression levels of $M H C-\Pi, I L-8$ and $I g M$ in the head kidney and liver (central organs), as well as gill tissue (mucosal surface) of juvenile rainbow trout. Materials and Methods: Juvenile rainbow trout were immunized with gamma-irradiated and formalin inactive trophonts with/without alginate nanoparticles against Ichthyophthirius multifiliis. On day 20 after bath-immunization, fish in all the treatments, except negative control, were exposed to live trophonts. On the $30^{\text {th }}$ day, fish tissues were analyzed by real-time PCR. Results: The IL-8 expression up-regulated in the kidney, hepatic and gill of immunized fish with irradiated and formalin inactive trophonts plus alginate nanoparticles and non-immunized fish challenged with live trophonts $(P<0.05)$. The MHC-Il showed up-regulation in gill and kidney of immunized fish and non-immunized fish challenged with live trophonts while hepatic $M H C-\Pi$ was up-regulated in immunized fish with formalin inactive trophonts plus alginate nanoparticles $(P<0.05)$. A significant increase in the IgM expression was detected in gills of immunized fish with irradiated trophonts with/without alginate nanoparticles and formalin inactive trophonts plus alginate nanoparticles $(P<0.05)$. The renal $\lg M$ showed up-regulation in all of treatments $(P<0.05)$. A significant increase in the hepatic IgM expression was in immunized fish via irradiated trophonts with/ without alginate nanoparticles $(P<0.05)$. Conclusion: These findings indicated that the higher expression of IgM, MHC-II and IL-8 at the gill, kidney and liver could prove the potential of the entire treatments to enhance both mucosal and systemic immune responses in immunized fish with gamma irradiated trophonts against I. multifiliis.
\end{abstract}

Keywords: Rainbow trout, gamma- irradiated Ichthyophthirius multifiliis, alginate nanoparticles, systemic immune response.

\section{INTRODUCTION}

The ciliated protozoan Ichthyophthirius multifiliis (I. multifiliis) is a large and rather important parasite of freshwater fish that causes 'white spot disease' which is leading to sudden death of fish worldwide $(1,2)$. Chemotherapy by chemical agents is difficult to administer and useless after its penetration of skin and gills.
Prior studies demonstrated that fish develop both systemic and mucosal immune responses and protection after treatment with $I$. multifiliis antigens $(3,4,5,6)$. Thus, immunization against $I$. multifiliis and immunotherapies are good alternative methods for chemotherapy (2). Besides, applying a convenient adjuvant can increase the potential of vaccines. The biodegradable and biocompatible polymers, 
such as alginate, have promising and safety systems to be used as adjuvant. This polysaccharide is found naturally in brown algae and some bacteria, such as Azotobacter vinelandii and Pseudomonas (7). The adjuvant effects of alginate were proved in previous studies (8-14).

Although, I. multifiliis is parasitic on the mucosal surfaces of the skin, gills and nose, innate adaptive immune responses can also be induced in systemic organs of some fish species following this sub-lethal infection (15). In our previous study, an up-regulation of IgM in the skin of the rainbow trout from day 20 to day 30 after immunization with gamma-irradiated and formalin inactive trophonts plus alginate nanoparticles were observed (16). Since there is no information about the immunoprotective role of these inactive trophonts on systemic immune responses, present study was designed. In this study, we investigated the expression genes of renal, hepatic (as central organs) and gill (as mucosal surface) $M H C-\Pi, I L-8$ and $I g M$ in the context of treated rainbow trout with a gamma irradiated I. multifiliis trophonts plus alginate nanoparticles compared to formalin inactive $I$. multifiliis and live trophonts to evaluate the mucosal and systemic immunity against I. multifiliis.

\section{MATERIALS AND METHODS}

\section{Fish}

Juvenile rainbow trout (Oncorhynchus mykiss) (mean body weight $74-40$ g) were kept in $300 \mathrm{~L}$ running water (flow rate $0.5 \mathrm{Lit} / \mathrm{s}$ ) polyethylene tanks. It was continuously supplied with aerated water, temperature $15 \pm 1{ }^{\circ} \mathrm{C}$, dissolved oxygen $5.2 \mathrm{ppm}$ under natural photoperiod (10L:14D). Fish were acclimatized to the experimental rearing condition for 14 days on a commercial pelleted diet (Behparvar, Iran).

\section{Gamma-irradiated and formalin inactive trophonts procedure}

Gamma-irradiated trophonts were prepared as described previously (17). Trophonts of
I. multifiliis used in this study were obtained from an infected pet fish. In brief, fifty fish were infected with I. multifiliis via a high dose of collected live trophonts by immersion method. Exposure was performed in the dark for $8 \mathrm{hrs}$. Fish were kept for 5 days at $20{ }^{\circ} \mathrm{C}$ and then trophonts were collected with 200-mesh sieve, examined under light microscope for survival and counted. Live trophonts were immediately used for preparing the gamma-irradiated or formalin inactive trophonts. For irradiation, gamma cell "Nordian", model 220 with dose rate of $0.22 \mathrm{~Gy} / \mathrm{sec}$ and $20469 \mathrm{Ci}$ activities and a dose of 170 Gy was used. For formalin inactivation, live trophonts were suspended in 3\% formalin, incubated for $2 \mathrm{hrs}$ at room temperature, and centrifuged at $3000 \times \mathrm{g}$ for $2 \mathrm{~min}$. Then, the supernatants were removed and washed 3 times with $1 \mathrm{ml}$ of $0.15 \mathrm{M}$ sterile phosphate buffered saline (PBS) ( $\mathrm{pH}=7.4)$. After washing, the formalin-treated trophonts were harvested by centrifugation at $3500 \times \mathrm{g}$ for $3 \mathrm{~min}{ }^{(16)}$.

\section{Alginate nanoparticles}

Alginate nanoparticles were prepared on the basis of our previous report (18). Ergosan, (Schering Plough Aquaculture, UK) was suspended in sterile phosphate buffered saline $(0.15 \mathrm{M}, \mathrm{pH}=7.2)$, sonicated on ice for $30 \mathrm{~min}$ and centrifuged at $5000 \times \mathrm{g}$, for $15 \mathrm{~min}$. After precipitation in 2.5 volumes of $96 \%$ ethanol and heating at $40^{\circ} \mathrm{C}$, the dried precipitate was then milled to the mesh size of 53-125 $\mu \mathrm{m}$. Remaining powder was irradiated by cobalt- 60 gamma irradiator (PX-30 - Issledovapel, Russia) at a dose $30 \mathrm{kGy}(18,19)$. Dosimetry was performed with Fricke reference standard dosimetry system.

\section{Fish treatment design}

For the treatment procedures, fish were randomly allocated between 18 triplicate tanks at a density of 30 fish per $300 \mathrm{~L}$ aquarium and maintained continuously aerated free-flowing dechlorinated freshwater (at total 540 fish). The fish were treated for separate aquarium immersion (Dose rate $=100$ gamma-irradiated/ formalin inactive trophonts per 150 gram of fish body weight). The gamma-irradiated/formalin

Int. J. Radiat. Res., Vol. 19 No. 4, October 2021 
inactive trophonts and nanoparticles were applied to the fish as follows:

Control (C): Healthy fish as a negative control was kept untreated until termination of the experiment.

Treatment 1 (T1): Non-immunized fish challenged with 1000 live trophonts (as a positive control).

Treatment 2 (T2): Fish immunized with gamma-irradiated (170 Gray) trophonts.

Treatment 3 (T3): Fish immunized with gamma-irradiated (170 Gray) trophonts plus alginate nanoparticles.

Treatment 4 (T4): Fish immunized with formalin (3\%) inactive trophonts.

Treatment 5 (T5): Fish immunized with formalin (3\%) inactive trophonts plus alginate nanoparticles.

All the treatments, except $\mathrm{C}$ and $\mathrm{T} 1$, were administered for the second time on day 10 after the first immunization.

\section{Challenge trials}

On day 20 after the first immunization, the water flow was turned off, water reduced to $10 \mathrm{~L}$ in each tank and fish in all the treatments, except control group (C), were exposed to 10000 live trophonts with aeration, via bath method. Post challenge mortalities were recorded daily in both treated and the control groups for 3 weeks. During 3 weeks of experiment, percentage of survival rate was calculated for all treatments according to the following formula:

Survival rate $(\%)=100$ (Live juvenile fish Dead juvenile fish) / Live juvenile fish

\section{Sampling}

All samples for this study were taken the same method described by Sigh et al., (2004)(5). Five fish were sampled from each group at the $30^{\text {th }}$ day following the first immunization. They were gently transferred to a small plastic aquarium containing mild anesthetic (MS 222, $20 \mathrm{mg} / \mathrm{L})$. In the laboratory, fish were killed quickly by overdose of MS 222 (300 mg/L) and different tissues, including head kidney, liver and gill were aseptically dissected and subsequently snap-frozen in liquid nitrogen.

\section{RNA extraction and cDNA synthesis}

RNA extraction from the tissue samples was performed using TRIzol Reagent (SigmaAldrich), according to the manufacturer's instructions. Two $\mu \mathrm{L}$ of total extracted RNA from each sample were used in cDNA synthesis. The cDNA was generated using $1 \mu \mathrm{L}$ of random hexamer primer $(2 \mu \mathrm{g} / \mathrm{L}), 10 \mu \mathrm{L}$ of $2 \times$ first standard reaction, $10 \mathrm{mM} \mathrm{Mgcl} 2,1 \mathrm{mM}$ dNTPs and $2 \mu \mathrm{L}$ reverse transcriptase. The reactions were incubated at $25^{\circ} \mathrm{C}$ for $10 \mathrm{~min}$, follow by 50 min at $50^{\circ} \mathrm{C}$ and finally, $85^{\circ} \mathrm{C}$ for $5 \mathrm{~min}$ and stored at $-20^{\circ} \mathrm{C}$ until further use. To assess PCR efficiency, serial dilutions of standard cDNA preparation were used to generate the standard curve for each primer set.

\section{Quantitative PCR}

All qPCR assays were carried out in the Step One $^{\mathrm{TM}}$ Real-Time PCR System (Applied Biosystems, USA). The reactions contained $10 \mu \mathrm{l}$ SYBR $^{\circledR}$ Premix Ex Taq $^{\text {TM }}$ (Tli RNase H Plus), ROX plus (TaKaRa, Japan), $1 \mu \mathrm{l}$ of cDNA, $0.5 \mu \mathrm{l}$ of forward and reverse primer $(100 \mathrm{nM})$ and filled up with ultra-pure water to a final volume of 20 $\mu l$. All samples were run in triplicate. The quantitative PCR thermal cycling conditions were: initial incubation step at $50^{\circ} \mathrm{C}$ for $2 \mathrm{~min}$ and at $95^{\circ} \mathrm{C}$ for $2 \mathrm{~min}$ followed by 40 amplification cycles of $15 \mathrm{~s}$ at $95^{\circ} \mathrm{C}$ and $1 \mathrm{~min}$ at $60^{\circ} \mathrm{C}$. In order to detect the presence of non-specific amplification, control reactions without template were included for each primer set. At the end of each cycle, DNA melting curve analysis was performed in order to confirm the specificity of the PCR products.

Gene expression of the samples compared to the control was calculated according to the following equation, using RESC009 QPCR software (Qiagen, USA), and the Pfaffl method (20).

Ratio $=\left(\epsilon_{\text {target }}\right) \Delta \mathrm{c}_{\mathrm{T} \text { target }}($ control-sample $) /\left(\epsilon_{\mathrm{RPS} 11}\right)$ $\Delta \mathrm{c}_{\mathrm{T} \text { target }}$ (control-sample)

The PCR primers were designed using the primer 3 program based on sequences deposited in the Gene Bank (primer sequences and amplicon length listed in table 1). The primer 
sets included genes of immunoglobulin $(\operatorname{IgM})$, cytokine (IL-8) and cell receptor (MHC- $\Pi$ ). $\mathrm{B}$-actin was selected as a reference gene and subsequently for sample normalization (5). All primers were purchased from sigma Aldrich.

Table 1. The sequences of the forward and reverse primer as well as the amplicon length

\begin{tabular}{|c|c|c|c|}
\hline Gene & Sequence (5-3) & Size of amplicon (bp) & Accession number \\
\hline IL8.F & GAATGTCAGCCAGCCTTGTC & \multirow{2}{*}{162} & \multirow{2}{*}{ AJ279069 } \\
\hline IL8.R & TCCAGACAAATCTCCTGACCG & & \\
\hline IgM.F & TGCGTGTTTGAGAACAAAGC & \multirow{2}{*}{107} & \multirow{2}{*}{ АН014877.2 } \\
\hline IgM.R & GACGGCTCGATGATCGTAAT & & \\
\hline MHC-II.F & ATGTCGATGCCAATTGCCTTCTA & \multirow{2}{*}{236} & \multirow{2}{*}{ U20943 } \\
\hline MHC-II.R & TGTCTTGTCCAGTATGGCGCT & & \\
\hline$\beta$-Actin.F & CAGCCCTCCTTCCTCGGTAT & \multirow{2}{*}{110} & \multirow{2}{*}{ NM_001124235.1 } \\
\hline$\beta$-Actin. $R$ & AGCACCGTGTTGGCGTACA & & \\
\hline
\end{tabular}

\section{Statistical analysis}

All values were given as mean $\pm \mathrm{SD}$, which were means with $95 \%$ confidence intervals in triplicate. The results were subjected to variance analysis (ANOVA) followed by least significant differences (Tukey) test. Correlation coefficients were significant with $P<0.05$.

\section{RESULTS}

Figure 1 shows the results of percentage survival of juvenile rainbow trout for 3 weeks after the challenge trial. The results obtained revealed that the percentage of fish that survived in the all groups were $\mathrm{T} 1=47.23 \pm$ $5.12 \%, \mathrm{~T} 2=60.12 \pm 4.13 \%, \mathrm{~T} 3=83.45 \pm 4.51$ $\%, \mathrm{~T} 4=66.01 \pm 5.31 \%$, T5 $=76.82 \pm 4.62 \%$ and $90.67 \pm 4.82 \%$ for the negative control (C) that was healthy fish. The result indicated that the highest mortality rate was seen in the positive control group (T1) while the lowest mortality rate $(83.45 \pm 4.51 \%)$ in immunized fish with gamma-irradiated trophonts plus alginate nanoparticles (T3). There was no significant difference of mortality rate $(P=6.61)$ between T3 and negative control group (C).

In this study, expression profiles of cytokine, $I L-8$, gene in the liver, gill and head kidney tissues of rainbow trout after 30 days following the first immunization are shown in table 2. The renal
IL-8 showed an up-regulation at immunized fish with irradiated trophonts (T2), gamma-irradiated trophonts plus alginate nanoparticles (T3) and formalin inactive trophonts with alginate nanoparticles (T5) but hepatic $I L-8$ were significantly up-regulated at irradiated trophonts treatment (T2), gammairradiated trophonts plus alginate nanoparticles treatment (T3), formalin inactive trophonts plus alginate nanoparticles treatment (T5) and at rainbow trout infected with live trophonts of $I$. multifiliis (T5) $(P<0.05) . I L-8$ in gill changed significantly in all treatments to negative control group $(\mathrm{C})(\mathrm{P}<0.05)$ (table 2$)$.

Renal and gill $M H C-\Pi$ were significantly up-regulated at infected fish with live trophonts (T1) and immunized fish with gamma-irradiated trophonts (T2), gamma-irradiated trophonts plus alginate nanoparticles (T3) and formalin inactive trophonts plus alginate nanoparticles (T5) $(P<0.05)$ (figures 2 and 3). The hepatic $M H C$ $-\Pi$ was down-regulated at gamma-irradiated trophonts treatment (T2), gamma-irradiated trophonts plus alginate nanoparticles treatment (T3) significantly compare to formalin inactive trophonts plus alginate nanoparticles treatment (T5) $(P<0.05)$ (table 3).

The renal IgM showed expression with significant up-regulation at gamma-irradiated trophonts treatment (T2), gamma-irradiated trophonts plus alginate nanoparticles treatment 
(T3) formalin inactive trophonts treatment (T4) and formalin inactive trophonts plus alginate nanoparticles treatment (T5) and hepatic IgM was up-regulated at gamma- irradiated trophonts treatment (T2), irradiated trophonts plus alginate nanoparticles treatment (T3) formalin inactive trophonts plus alginate nanoparticles treatment (T5) $(P<0.05)$ (table 4). The gene of $I g M$ in gill exhibited a significantly increase in mRNA expression level at gamma-irradiated trophonts plus alginate nanoparticles treatment to the other groups (T3) $(P<0.05)$ (table 4).

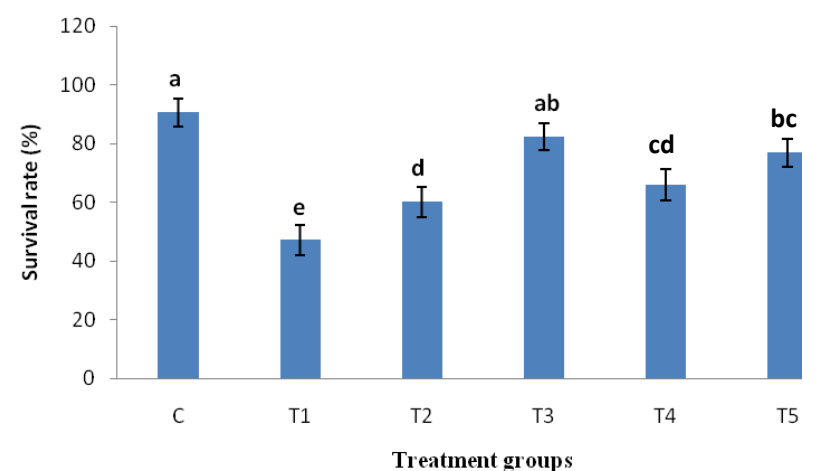

Figure 1. The survival rate (\%) of juvenile rainbow trout in different treatments; C: Healthy fish, negative control; T1: Non -immunized rainbow trout challenged with live trophonts of Ichthyophthirius multifiliis; T2: Rainbow trout immunized via gamma-irradiated trophonts; T3: Rainbow trout immunized via gamma-irradiated trophonts plus alginate nanoparticles; T4: Rainbow trout immunized via formalin inactive trophonts; T5: Rainbow trout immunized via formalin inactive trophonts plus alginate nanoparticles.

Table 2. Expression of IL-8 gene in the liver, head kidney and gill of treated juvenile rainbow trout against Ichthyophthirius multifiliis relative to the $\beta$-actin gene during 30 days. Different lower case letters $(a-c)$ within the same row (different tissues) indicate significant differences $(P<0.05)$.

\begin{tabular}{|c|c|c|c|c|c|c|}
\hline Treatments & C & \multirow{2}{*}{ T1 } & \multirow{2}{*}{ T2 } & T3 & T4 & T5 \\
\cline { 1 - 5 } Tissues & & & & & & \\
\cline { 1 - 5 } Head & $0.33 \pm$ & $0.61 \pm$ & $1.26 \pm$ & $1.23 \pm$ & $0.65 \pm$ & $0.98 \pm$ \\
\cline { 1 - 5 } kidney & $0.13^{\mathrm{c}}$ & $0.21^{\mathrm{abc}}$ & $0.5^{\mathrm{a}}$ & $0.33^{\mathrm{a}}$ & $0.12^{\mathrm{b}}$ & $0.14^{\mathrm{a}}$ \\
\hline \multirow{2}{*}{ Gill } & $0.35 \pm$ & $0.85 \pm$ & $1.11 \pm$ & $0.91 \pm$ & $0.49 \pm$ & $0.78 \pm$ \\
& $0.12^{\mathrm{b}}$ & $0.33^{\mathrm{a}}$ & $0.09^{\mathrm{a}}$ & $0.36^{\mathrm{a}}$ & $0.22^{\mathrm{ab}}$ & $0.18^{\mathrm{a}}$ \\
\hline & $0.49 \pm$ & $1.42 \pm$ & $1.35 \pm$ & $1.01 \pm$ & $1.08 \pm$ & $1.09 \pm$ \\
& $0.05^{\mathrm{b}}$ & $0.31^{\mathrm{a}}$ & $0.42^{\mathrm{a}}$ & $0.36^{\mathrm{a}}$ & $0.33^{\mathrm{a}}$ & $0.32^{\mathrm{a}}$ \\
\hline
\end{tabular}

Values are represented as means \pm SEM of three replicates treatments. C: Healthy fish, negative control; T1: Non-immunized rainbow trout challenged with live trophonts of Ichthyophthirius multifiliis; T2: Rainbow trout immunized via irradiated trophonts; T3: Rainbow trout immunized via irradiated trophonts plus alginate nanoparticles; T4: Rainbow trout immunized via formalin inactive trophonts; T5: Rainbow trout immunized via formalin inactive trophonts plus alginate nanoparticles.

Int. J. Radiat. Res., Vol. 19 No. 4, October 2021
Table 3. Expression of MHC-II gene in the liver, head kidney and gill of treated juvenile rainbow trout against

Ichthyophthirius multifiliis relative to the $\beta$-actin gene during 30 days. Different lower case letters $(\mathrm{a}-\mathrm{c})$ within the same row (different tissues) indicate significant differences $(P<0.05)$.

\begin{tabular}{|c|c|c|c|c|c|c|}
\hline Treatments & C & \multirow{2}{*}{ T1 } & T2 & T3 & T4 & T5 \\
\cline { 1 - 6 } Tissues & & & & & & \\
\cline { 1 - 5 } Head & $1.01 \pm$ & $1.62 \pm$ & $1.45 \pm$ & $2.03 \pm$ & $0.95 \pm$ & $1.75 \pm$ \\
kidney & $0.32^{\mathrm{b}}$ & $0.6^{\mathrm{ab}}$ & $0.3^{\mathrm{ab}}$ & $0.4^{\mathrm{a}}$ & $0.31^{\mathrm{b}}$ & $0.49^{\mathrm{ab}}$ \\
\hline \multirow{2}{*}{ Liver } & $1.12 \pm$ & $1.39 \pm$ & $0.79 \pm$ & $0.98 \pm$ & $1.34 \pm$ & $1.88 \pm$ \\
& $0.2^{\mathrm{b}}$ & $0.4^{\mathrm{ab}}$ & $0.2^{\mathrm{b}}$ & $0.19^{\mathrm{b}}$ & $0.5^{\mathrm{ab}}$ & $0.46^{\mathrm{a}}$ \\
\hline \multirow{2}{*}{ Gill } & $0.48 \pm$ & $1.35 \pm$ & $1.17 \pm$ & $1.42 \pm$ & $0.94 \pm$ & $1.29 \pm$ \\
& $0.52^{\mathrm{c}}$ & $0.31^{\mathrm{a}}$ & $0.63^{\mathrm{a}}$ & $0.62^{\mathrm{a}}$ & $0.47^{\mathrm{ab}}$ & $0.66^{\mathrm{a}}$ \\
\hline
\end{tabular}

Values are represented as means \pm SEM of three replicates treatments. C: Healthy fish, negative control; T1: Non-immunized rainbow trout challenged with live trophonts of Ichthyophthirius multifiliis; T2: Rainbow trout immunized via irradiated trophonts; T3: Rainbow trout immunized via irradiated trophonts plus alginate nanoparticles; T4: Rainbow trout immunized via formalin inactive trophonts; T5: Rainbow trout immunized via formalin inactive trophonts plus alginate nanoparticles.

Table 4. Expression of IgM gene in the liver, head kidney and gill of treated juvenile rainbow trout against Ichthyophthirius multifiliis relative to the $\beta$-actin gene during 30 days. Different lower case letters $(a-c)$ within the same row (different tissues) indicate significant differences $(P<0.05)$.

\begin{tabular}{|c|c|c|c|c|c|c|}
\hline Treatments & C & \multirow{2}{*}{ T1 } & T2 & T3 & T4 & T5 \\
\cline { 1 - 5 } Tissues & & & & & & \\
\cline { 1 - 5 } Head & $3.2 \pm$ & $3.14 \pm$ & $6.2 \pm$ & $6.06 \pm$ & $6.06 \pm$ & $6.38 \pm$ \\
kidney & $0.89^{\mathrm{b}}$ & $0.38^{\mathrm{b}}$ & $1.7^{\mathrm{a}}$ & $1.6^{\mathrm{a}}$ & $1.01^{\mathrm{a}}$ & $1.66^{\mathrm{a}}$ \\
\hline \multirow{2}{*}{ Liver } & $2.01 \pm$ & $2.86 \pm$ & $3.69 \pm$ & $4.27 \pm$ & $3.02 \pm$ & $3.84 \pm$ \\
& $0.51^{\mathrm{c}}$ & $1^{\mathrm{abc}}$ & $1.2^{\mathrm{ab}}$ & $1.4^{\mathrm{a}}$ & $1.07^{\mathrm{abc}}$ & $1.14^{\mathrm{ab}}$ \\
\hline \multirow{2}{*}{ Gill } & $1.49 \pm$ & $1.26 \pm$ & $3.64 \pm$ & $4.27 \pm$ & $1.07 \pm$ & $3.69 \pm$ \\
& $0.46^{\mathrm{b}}$ & $0.41^{\mathrm{b}}$ & $0.5^{\mathrm{a}}$ & $1.2^{\mathrm{a}}$ & $0.35^{\mathrm{b}}$ & $0.47^{\mathrm{a}}$ \\
\hline
\end{tabular}

Values are represented as means \pm SEM of three replicates treatments. C: Healthy fish, negative control; T1: Non-immunized rainbow trout challenged with live trophonts of Ichthyophthirius multifiliis; T2: Rainbow trout immunized via gamma-irradiated trophonts; T3: Rainbow trout immunized via gamma-irradiated trophonts plus alginate nanoparticles; T4: Rainbow trout immunized via formalin inactive trophonts; T5: Rainbow trout immunized via formalin inactive trophonts plus alginate nanoparticles.

\section{DISCUSSION}

In this study, non-immunized fish (T1) challenged with live trophonts showed infection and died. This is similar to results of study of infected Nile Tilapia and Basa ${ }^{6}$ ish (Pangasius bocourti) that showed few days to death $(21,22)$. The immunized fish with gamma-irradiated and formalin inactive trophonts with/without alginate nanoparticles exhibited light infection with high survival rate (\%). The survival rate (\%) observed in this study was similar to the 
other fish immunization trials that trophonts provided survival to live trophonts challenge in immunized fish compared to the nonimmunized control $(23,24,25,26,27)$.

Rainbow trout reacted to I. multifiliis by upgrading innate and adaptive immune genes to express at the mucosal immune surfaces and in the central immune organs $(28,15) . I L-8$ is an important Cys-Xaa-Cys (CXC) subgroup of chemokines, and also a potent chemoattractant for neutrophils in local inflammation or injury sites $(29,30)$. The increase of $I L-8$ gene expression in local infection sites post-parasite infection were observed for I. multifiliis and C.goldsmidi in infection models; This could be an important factor in the extravasations and recruitment of neutrophils into the skin and gill, respectively ${ }^{6}$, 31,32). Skin and gill as mucosal organs can serve as the first line of defense against I. mutifiliis. Our previous studies have shown that $I L-8$ was up-regulated in the skin of rainbow trout immunized with gamma-irradiated and formalin inactive trophonts of I. multifiliis plus alginate nanoparticles (16). The results obtained from the current study were in line with the report of Heidarieh et al. (2015) that showed markedly $I L$ -8 gene expression upregulated in the head kidney, liver and gill tissues after fish treating with gamma-irradiated with/without alginate nanoparticles and formalin inactive trophonts plus alginate nanoparticles, which was further confirmed by newly reported on upregulating of the cytokines gene expression in both of the systemic and mucosal tissues of vaccinated catfish $(15,28)$. It was also found that $I L-8$ was upregulated in the liver, head kidney and gill of juvenile rainbow trout after infection with live $I$. multifiliis. Previous studies on catfish reported that the expression of cytokines increased in the head kidney, spleen and liver post I. multifiliis-infection $(34,33)$.

In this study, the expression profiles of MHC-II and $I L-8$ were similar, and both were significantly upregulated in the gill, liver and head kidney of juvenile rainbow trout at most time points after immunization against I. multifiliis. The MHCS are immunoglobulin superfamily member proteins that interact with T-cells (35). MHC-II mainly presents external peptides (Ags) to cell mediated immunity (36). These results suggested that renal and gill $M H C$-II gene related to the cell receptors were actively involved in the immune response to combat I. multiGiliis in juvenile rainbow trout. Our results are also in agreement with the study on the expression of MHC-II in fish (13) which showed these cell receptor genes were upregulated in the head kidney of immunized fish from 4 hrs to 10 days after immunization. An upregulation of TCR- $\beta$ and MHC-II genes were also demonstrated following experimental immunization of rainbow trout with a DNA vaccine against $I$. multifiliis (37). In our studies on juvenile rainbow trout also found that the expression of $M H C-I I$ genes was significantly unregulated in skin (16) and gill and head kidney after the bath-challenge with live I. multifiliis trophonts. Similar results of MHC-II were detected in the head kidney of rainbow trout post-infection with I. multifiliis theronts $(5,6)$.

Serum and mucosal antibodies were detected in fish immunized with live theronts (38). The antibody repertoires in teleost fish are more limited than in mammals (39). The most prevalent immunoglobulin in serum of fish is an $\operatorname{Ig} M$ gene (30). IgM mainly functions in the adaptive immune response in the systemic tissues of rainbow trout (15). IgM gene up-regulation was also reported by Olsen et al. (2011) in trout gill following immunization by IP injection of I. multifiliis theronts ${ }^{(40)}$. We here demonstrated a significant up-regulation of IgM gene in the gill and head kidney tissues following treatment with gamma-irradiated and formalin inactive trophonts with/without alginate nanoparticles at days 30 post-immunization in agreement with other reports (6). A previous experiment also showed an up-regulation of $\operatorname{IgM}$ in the skin of the rainbow trout from day 20 to day 30 after immunization with gamma-irradiated and formalin-inactive trophonts plus alginate nanoparticles (16). These results are indicators of production of antibodies in gill as local mucosal surface and head kidney as central immune organs of immunized rainbow trout against $I$. multifliis. Sigh etal. (2004) reported rainbow trout contained high titers of parasite-specific IgM in the serum in the head kidney after

Int. J. Radiat. Res., Vol. 19 No. 4, October 2021 
I. multifiliis infection (5). According to the obtained results, IgM might be generated in the head kidney and transported to other lymphoid organs by blood circulation (23).

Formalin inactive trophonts as well as gamma-irradiated trophonts successfully can induce antibody-mediated protection rainbow trout, but use of gamma radiation method can abolish chemical contaminants and penetrates pathogens to destroy nucleic acids without damaging the pathogen surface antigens. Moreover, there is no need to remove any chemical residue after inactivation. Although some gamma-irradiated trophonts showed no surprising results compared to live attenuated- or chemically inactivated vaccine antigen, the demand for the application of gamma radiation is increasing for the development of the safe vaccine for fish in aquaculture $(41,42,43)$.

Furthermore, this study focused on the expression of some genes (IgM, MHC-II and IL-8) related to innate and adaptive immune responses in the liver, head kidney (as central immune organs) and gill (as mucosal immune surface) tissues of non-immunized and immunized rainbow trout with gammairradiated and formalin inactive trophonts plus alginate nanoparticles as adjuvant against I. multifiliis. The acquired results showed the entire treatments can have positive effects on both antibody and cell mediated immune responses at local and systemic level as seen by gene expression in all examined tissues.

\section{Conflicts of interest: Declared none.}

\section{REFERENCES}

1. Aihua $L$ and Buchmann K (2001) Temperature-and salinitydependent development of a Nordic strain of Ichthyophthirius multifilis from rainbow trout. Journal of Applied Ichthyology, 17: 273-276.

2. Maki JL and Dickerson HW (2003) Systemic and Cutaneous Mucus antibody responses of channel catfish immunized against the protozoan parasite Ichthyophthirius multifiliis. Clinical and Diagnostic Laboratory Immunology, 10(5): 876 $-881$.

3. Wahli T and Meier W (1985) Ichthyophthiriasis in trout: Int. J. Radiat. Res., Vol. 19 No. 4, October 2021 investigation of natural defense mechanisms. In: Ellis $A E$, editor. London: Academic Press. Fish and shellfish pathology, 347-352.

4. Sigh J and Buchmann K (2001) Comparison of immobilization assays and enzyme-linked immunosorbent assays for detection of rainbow trout antibody-titres against Ichthyophthirius multifiliis Fouquet, 1876. Journal of Fish Diseases, 24: 49-51.

5. Sigh J, Lindenstrom T, Buchmann K (2004a) Expression of pro-inflammatory cytokines in rainbow trout (Oncorhynchus mykiss) during an infection with Ichthyophthirius multifiliis. Fish and Shellfish Immunology, 7: 7686.

6. Sigh J, Lindenstrom T, Buchmann K (2004b) The parasitic ciliate Ichthyophthirius multifiliis induces expression of immune relevant genes in rainbow trout, Oncorhynchus mykiss (Walbaum). Journal of Fish Diseases, 27: 409-417.

7. Gombotz WR, Wee SF (2012) Protein release from alginate matrices. Advanced Drug Delivery Reviews, 31: 267-285.

8. Borges O, Silva M, De Sousa A, Borchard G, Junginger HE, Cordeiro-Da-Silva A (2008) Alginate coated chitosan nanoparticles are an effective subcutaneous adjuvant for hepatitis B surface antigen. International Immunopharmacology, 8(13-14): 1773-1780.

9. Tafaghodi M, Tabasi S, Payana M (2007) Alginate Microsphere as a Delivery System and Adjuvant for Autoclaved Leishmania major and Quillaja Saponin: Preparation and Characterization. Iranian Journal of Pharmaceutical Sciences, 3(2): 61-68.

10. Chen L, Klaric G, Wadsworth S, Jayasinghe S, Kuo TY, Evensen $O$ (2014) Augmentation of the antibody response of Atlantic salmon by oral administration of alginateencapsulated IPNV antigens. PLoS One, 9(10): e109337.

11. Leal CAG, Carvalho-Castro GA, Sacchetin PSC, Lopes CO, Moraes ÂM, Figueiredo HCP (2014) Oral and parenteral vaccines against Flavobacterium columnare: evaluation of humoral immune response by ELISA and in vivo efficiency in Nile tilapia (Oreochromis niloticus) Aquaculture International, 18: 657-666.

12. Tian J, Sun X, Chen X (2008) Formation and oral administration of alginate microspheres loaded with pDNA coding for lymphocystis disease virus (LCDV) to Japanese flounder. Fish and Shellfish Immunology, 24: 592-599.

13. Ana I, Saint-Jean SR, Pérez-Prieto SI (2010) Immunogenic and protective effects of an oral DNA vaccine against infectious pancreatic necrosis virus in fish. Fish and Shellfish Immunology, 28(4): 562-70.

14. Altun S, Kubilay S, Ekici S, Didinen B, Diler O (2010) Oral vaccination against lactococcosis in rainbow trout (Oncorhynchus mykiss) using sodium alginate and poly (lactide-co-glycolide) carrier. Kafkas Universitesi Veteriner Fakultesi Dergisi, 16: 211-217.

15. Wang Q, Yu Y, Zhang X, Xu Z (2019) Immune responses of fish to Ichthyophthirius multifiliis (Ich): A model for understanding immunity against protozoan parasites. Developmental \& Comparative Immunology, 93: 93-102.

16. Heidarieh M, Diallo A, Moodi S, Taghi-nejad V, Akbari M, Monfaredan A (2015) Gene expression analysis in rainbow trout (Oncorhynchus mykiss) skin: Immunological responses to radiovaccine against Ichthyophthirius multifiliis. Revue de médecine vétérinaire, 166: 233-242. 
17. Heidarieh $M$, Hedayati rad $M$, Mirvaghefi AR, Diallo $A$, Mousavi Sh, Sheikhzadeh N, Shahbazfar AA (2014) Effect of gamma-irradiation on inactivation of Ichthyophithirius multifiliis trophonts and its efficacy on host response in experimentally immunized rainbow trout (Oncorhynchus mykiss). Turkish Journal of Veterinary and Animal Sciences, 38: 388-393.

18. Heidarieh M, Borzouei A, Rajabifar S, Ziaie F, Shafiei Sh (2012) Effects of gamma irradiation on antioxidant activity of Ergosan. Int J Radiat Res, 9: 245-249.

19. Heidarieh M, Daryalal F, Mirvaghefi AR, Shahbazfar AA, Moodi S, Heidarieh H (2014) Histopathological alterations induced by irradiated alginate in rainbow trout (Oncorhynchus mykiss). Journal of Applied Ichthyology, 30: 543-545.

20. Pfaffl MW (2001) A new mathematical model for relative quantification in real-time RT-PCR. Nucleic Acids Research, 29(9): e45.

21. Xu DH, Shoemarker CA, LaFrentz BR (2014) Enhanced susceptibility of hybrid tilapia to Flavobacterium columnare after parasitism by Ichthyophthirius multifiliis. Aquaculture, 430: 44-49.

22. Uawonggul N, Rattanamalee C, Daduang S (2018) Immunization of Basa fish (Pangasius bocourti) against Ichthyophthirius multifiliis with live and sonicated trophonts. Iranian Journal of Fisheries Sciences, 17(4): 763-775.

23. Xu DH, Zhang QZ, Shoemaker CA, Zhang D (2016) Molecular immune response of channel catfish immunized with live theronts of Ichthyophthirius multifiliis. Fish and Shellfish Immunology, 54: 86-92.

24. Xu DH, Klesius PH, Shoemaker CA (2008) Effect of immunization of channel catfish with inactivated trophonts on serum and cutaneous antibody titers and survival against Ichthyophthirius multifiliis. Fish and Shellfish Immunology, 26: 614-618.

25. Dalgaard M, Buchmann K, Li A (2002) Immunization of rainbow trout fry with Ichthyophthirius multifiliis sonicate: protection of host and immunological changes. Bulletin of the European Association of Fish Pathologists, 22: 287-97.

26. Ling KH, Sin YM, Lam TJ (1993) Protection of goldfish against some common ectoparasitic protozoans using Ichthyophthirius multifiliis and Tetrahymena pyriformis for vaccination. Aquaculture, 116: 303-14.

27. He J, Yin Z, Xu G, Gong Z, Lam TJ, Sin YM (1997) Protection of goldfish against Ichthyophthirius multifiliis by immunization with a recombinant vaccine. Aquaculture, 158: 110.

28. Syahputra K, Kania PW, Al-Jubury A, Marnis H, Setyawan AC, Buchmann K (2019) Differential immune gene response in gills, skin, and spleen of rainbow trout $O n$ corhynchus mykiss infected by Ichthyophthirius multifiliis. PLoS One, 14(6): e0218630.

29. Schroder JM, Mrowietz U, Morita E, Christophers E (1987) Purification and partial biochemical characterization of a human monocyte-derived, neutrophil-activating peptide that lacks interleukin 1 activity. Journal of Immunology, 139: 3474-3483.

30. Mukaida N, Harada A, Matsushima K (1998) Interleukin-8 (IL-8) and monocyte chemotactic and activating factor (MCAF/MCP-1), chemokines essentially involved in inflammatory and immune reactions. Cytokine \& Growth Factor
Reviews, 9: 9-23.

31. Covello JM, Bird S, Morrison RN, Battaglene SC, Secombes CJ, Nowak BF (2009) Cloning expression analysis of three striped trumpeters (Latris lineata) pro-inflammatory cytoalpha, IL-1beta and IL-8, in response to infection by the ectoparasitic, Chondracanthu goldsmidi. Fish and shellfish Immunology, 26: 773-786.

32. Lindenstrøma T, Secombes CJ, Buchmann K (2004) Expression of immune response genes in rainbow trout skin induced by Gyrodactylus derjavini infections. Veterinary Immunology and Immunopathology, 97: 137-148.

33. Zhao F, Li YW, Pan HJ, Shi CB, Luo XC, Li AX, Wu SQ (2013) Expression profiles of toll-like receptors in channel catfish (Ictalurus punctatus) after infection with Ichthyophthirius multifilis. Fish and Shellfish Immunology, 35: 993-997.

34. Moreira GS, Shoemaker CA, Zhang D, Xu DH (2017) Expression of immune genes in skin of channel catfish immunized with live theronts of Ichthyophthirius multifiliis. Parasite Immunology, 39 (1).

35. Moore LJ, Somamoto T, Lie KK, Dijkstra JM, Hordvik I (2005) Characterisation of salmon and trout $\mathrm{CD}_{8}$ alpha and $\mathrm{CD}_{8}$ beta. Molecular Immunology, 42: 1225-1234.

36. Grimholt U, Larsen $S$, Nordmo R, Midtlyng P, Kjoeglum $S$, Storset A, Saeb $\varnothing$ S, Stet RJ (2003) MHC polymorphism and disease resistance in Atlantic salmon (Salmo salar); facing pathogens with single expressed major histocompatibility class I and class II loci. Immunogenetics, 55, 210-219.

37. von Gersdorff Jorgensen L, Sigh J, Kania PW, HoltenAndersen L, Buchmann K, Clark T, Skou Rasmussen J, Einer -Jensen K, Lorenzen N (2012) Approaches towards DNA vaccination against a skin ciliate parasite in fish. PLoS One, 7: e48129.

38. Xu DH, Klesius PH, Shelby RA (2004) Immune responses and host protection of channel catfish, Ictalurus punctatus (Rafinesque), against Ichthyophthirius multifiliis after immunization with live theronts and sonicated trophonts. Journal of Fish Diseases, 27: 135-141.

39. Solem ST and Stenvik J (2006) Antibody repertoire development in teleosts-a review with emphasis on salmonids and Gadus morhua L. Developmental and Comparative Immunology, 30: 57-76.

40. Olsen MM, Kania PW, Heinecke RD, Skjoedt K, Rasmussen KJ, Buchmann K (2011) Cellular and humoral factors involved in the response of rainbow trout gills to Ichthyophthirius multifiliis infections: molecular and immunohistochemical studies. Fish and shellfish Immunology, 30 : 859-869.

41. Datta M (2006) The 5 component a cellular pertussis vaccine combined with tetanus and diphtheria toxoids was efficacious in adolescents and adults. Evidence-Based Complementary and Alternative Medicin, 11: 51.

42. Datta SK, Okamoto S, Hayashi T, Shin SS, Mihajlov I, Fermin A, Guiney DG, Fierer J, Raz E (2006) Vaccination with irradiated Listeria induces protective T cell immunity. Immunity, 25: 143-52.

43. Magnani DM, Harms JS, Durward MA, Splitter GA (2009) Non-dividing but metabolically active gamma-irradiated Brucella melitensis is protective against virulent $B$. melitensis challenge in mice. Infection and Immunity, 77: 5181-5189.

Int. J. Radiat. Res., Vol. 19 No. 4, October 2021 